Scientific Journal of October 6 University

ISSN (Print): 2314-8640

ISSN (Electronic): 2356-8119

Published by October 6 University @ All Rights Reserved

Available online at: http:// sjou.journals.ekb.eg

Original Article
Citation: Motawi et al., (2017). Exenatide prevents diabetic nephropathy in a rat model of type 2 diabetes mellitus (fat-fed, streptozotocin-treated rat). Sci. J. of Oct. 6 Univ.4(1), 9-19.

Copyright: (C) 2017 Motawi et al. This is an open-access article distributed under the terms of the Creative Commons Attribution License, which permits unrestricted use, distribution, and reproduction in any medium, provided the original author and source are credited.

\title{
Exenatide prevents diabetic nephropathy in a rat model of type 2 diabetes mellitus (fat- fed and streptozotocin-treated rats)
}

\author{
Tarek Kamal Motawi ${ }^{1}$, Hanan Muhammad Abdelgawad ${ }^{1}$, Shaymaa Galal ${ }^{2}$ and Sherine Maher \\ Rizk $^{1}$
}

${ }^{1}$ Prof. of Biochemistry, Biochemistry Department, Faculty of Pharmacy, Cairo University, Egypt

${ }^{2}$ Demonstrator of Biochemistry, Biochemistry Department, Faculty of Pharmacy, October 6 University, Egypt

\section{Received: 10-04-2017/ Revised: 4-06-2017 / Accepted: 27-06-2017}

\begin{abstract}
Diabetic nephropathy (DN) is one of the most serious complications of diabetes mellitus. Our study aims to demonstrate the effectiveness of exenatide, glucagon like peptide-1 receptor agonist, on insulin release and renal functions in type 2 diabetes mellitus (T2DM) rats enduring DN. T2DM was induced in male wistar-albino rats by single streptozotocin injection $(40 \mathrm{mg} / \mathrm{kg}$, i.p.) followed by high fat diet for 10 weeks, while the treatment group received exenatide injection $(10 \mu \mathrm{g} / \mathrm{kg} /$ day, i.p.) one week after STZ injection along for 9 weeks. Animals were monitored by periodic biochemical testing of fasting serum glucose (FSG), cystatin-C, creatinine and urinary protein levels. At the end of the study (10 weeks) serum total nitrite/nitrate $\left(\mathrm{NO}_{\mathrm{x}}\right)$, adiponectin, C-peptide and amylase activity were investigated. Renal total triglycerides; hydroxy proline (HP), and DNA fragmentation were estimated, as well as renal enzymatic activity and mRNA expression level of glucose-6-phosphatase. Exenatide showed significant reduction in FSG, serum creatinine, cystatin- C, and urinary protein levels in diabetic rats. It favored increased serum $\mathrm{NO}_{\mathrm{x}}$, serum adiponectin as well as C-peptide which reflects improving in insulin sensitivity and release respectively. Further, exenatide diminished renal DNA fragmentation, decreased renal triglyceride, HP contents, and glucose-6-phosphatase enzyme activity and expression levels in diabetic rats. Our data donate further credence for the effectiveness of exenatide against diabetic renal complications, through different aspects including reduction of renal DNA fragmentation and gluconeogenesis in addition to the previously reported mechanisms.
\end{abstract}

Key Words: Diabetic nephropahy; exenatide; streptozotocin; high fat diet; gluconeogenesis; apoptosis.

\section{Introduction}

Uncontrolled diabetes mellitus (DM) leads to serious complications particularly vascular related complications which divided into microvascular (e.g., nephropathy, neuropathy, and retinopathy) and macrovascular (e.g., coronary artery disease, peripheral artery disease, and stroke) (Fowler, 2008). Diabetic nephropathy (DN) is one of the most common complications of DM (Tuttle and Anderson, 2003) and is the driving cause of endstage renal disease (ESRD) in developed countries. About $20-30 \%$ of patients with type 1 DM (T1DM) or type 2 DM (T2DM) develop evidence of nephropathy (Shlipak, 2009). In many countries, including the Middle East, the majority of diabetic patients starting kidney replacement therapy were have T2DM rather than T1DM (Obineche and
Adem, 2005). An estimated $9.1 \%$ of the populations from the Middle Eastern/North African region have T2DM (32.8 million) in 2011 and this is projected to reach 60 million in 2030 (Badran and Laher, 2012).

The pathogenesis of DN appears to be multifactorial. Several genetic and environmental factors are likely to contribute its development and progression, while it is important to consider that hyperglycemia as a primary initiator of DN.

Hyperglycemia acts on renal endothelial and mesangial cells, podocytes and also tubular cells. Glomerular podocytes are highly specialized cells; their most prominent features are interdigitated foot processes with filtration slits in between (avenstädt et al., 2003).

*Corresponding Author Address: Dr: Shymaa Galal: Department of Biochemistry, Faculty of Pharmacy, MTI University, Egypt.

E-mail: d_shaimaa@hotmail.com 
These are bridged by the slit diaphragm, which plays a major role in establishing the selective permeability of the glomerular filtration barrier. Injury to podocytes leads to proteinuria, a hallmark of most glomerular diseases. ${ }^{6}$ In addition, oxidative stress, inflammatory cytokines, advanced glycation end products (AGEs), abnormal lipid metabolism as well as renal accumulation of lipids have been suggested to play an important role in the pathogenesis of DN (Keane, 2000). An increase in the albumin excretion rate eventually leads to microalbuminuria which is the earliest index of $\mathrm{DN}$, a risk factor for the progression of overt diabetic renal disease (Mogensen, 1997). However, microalbuminuria may develop because of hypertension or/and insulin resistance (Lin et al., 2009), therefore, there is a demand to identify new sensitive and specific markers for screening and assessing incipient DN and monitoring responses to therapy. Cystatin $\mathrm{C}$ is a small $13-\mathrm{kDa}$ protein that is produced at a constant rate by all nucleated cells, due to its small size it is freely filtered by the glomerulus, and is not secreted but is fully reabsorbed by the renal tubules to be broken down there. Cystatin $\mathrm{C}$ had found to be more sensitive marker to actual changes in glomerular fiteration rate (GFR) in the early stages of chronic kidney disease than serum creatinine based GFR estimates (Pucci et al., 2007). So throughout our study we try to follow the progress of DN through measurement of both serum cystatin $\mathrm{C}$ and proteinuria.

Glucagon-like peptide-1 (GLP-1) is an incretin hormone secreted from the intestinal L-cells in animals and human and is responsible for the majority of nutrient stimulated insulin secretion (Meier et al., 2002). However, treatment of diabetics with human GLP-1 is ineffective because of rapid dipeptidyl peptidase IV (DPPIV)-mediated human GLP-1 degradation in the circulation. Exenatide is the first incretin mimetic and agonist of the GLP-1 receptor (GLP-1R) that has been shown, in controlled randomized studies, to significantly attenuate insulin resistance and improve glycaemic control in patients with T2DM (Nikolaidis et al., 2004). GLP-1R is a G proteincoupled receptor linked to the activation of the adenylate cyclase pathway (Thorens, 1992), GLP$1 \mathrm{R}$ is expressed in a variety of tissues, including pancreatic $\alpha$ and $\beta$ cells, stomach, lungs, heart, and kidneys (Bullock et al., 1996). Studies of exenatide in patients with T2DM showed enhanced glucosestimulated insulin secretion, suppressed glucosedependent glucagon secretion, and delayed gastric emptying, leading to reductions in both fasting and postprandial blood glucose levels (Riddle et al., 2006).

Studies have also reported that exenatide treatment led to reductions in $\mathrm{HbA} 1 \mathrm{c}$ and weight loss in both short- and long-term studies (Klonoff et al., 2008), as well as improving $\beta$-cell proliferation and islet neogenesis, hypertension, insulin sensitivity, vasodilatation, and renal diuresis in animal studies (Gedulin et al., 2005).

In the present study, the high fat diet-streptozotocin (HFD- STZ) induced DN rat model is used to investigate additional potential protective effects of synthetic GLP-1 mimetic, Exenatide (Byetta ${ }^{\circledR}$ ), against nephrotic complications of T2DM.

\section{Materials and methods}

\subsection{Drug and chemicals}

STZ was purchased from Sigma-Aldrich Chemical Company, St. Louis, MO, USA. The feeding ingredients, such as cholesterol and sheep fat, were obtained from commercial sources. Exenatide (Byetta $^{@} 10 \mu \mathrm{g}$ prefilled pen) was from Amylin Pharmaceuticals, Inc., San Diego, CA. Other chemicals and organic solvents were of analytical grade.

\subsection{Animals}

This study was performed in strict accordance with the guidelines of the Research Ethical Committee on Animal Care and Use of the Faculty of Pharmacy, Cairo University, Cairo, Egypt. Two months-old adult male Wistar albino rats weighing 180-200 g were kept for an initial adaptation period for one week before any experimental manipulation, having free access to water and pelleted standard rat chow diet ad libitum. They were kept on $12 \mathrm{~h} \mathrm{light/dark} \mathrm{cycle,} \mathrm{in} \mathrm{a} \mathrm{temperature}$ maintained at $\left(25 \pm 3^{\circ} \mathrm{C}\right)$.

\subsection{Experimental design \\ 2.3.1 Induction and assessment of diabetes}

For induction of T2DM, , rats were received single i.p. injection of STZ (40 mg/kg b.w) dissolved in 0.09 M citrate buffer (pH 4.7) (Sahin et al., 2007) followed by feeding HFD (Table 1) for 10 weeks (Yokoyama et al., 2010 and Arya et al., 2011). In our study only rats only with random blood glucose concentrations $\geq 200 \mathrm{mg} / \mathrm{dl}(\geq 11.1 \mathrm{mmol} / \mathrm{l})$ at 7 days after STZ injection were considered as diabetic. The respective normal control group received single i.p. injection of vehicle $0.09 \mathrm{M}$ citrate buffer in a dose volume of $1 \mathrm{ml} / \mathrm{kg}$ and kept on commercially available normal pellet diet till the end of the experiment.

Table (1) Composition of high fat diet (HFD).

\begin{tabular}{|l|c|}
\hline Ingredients & Diet $(\mathbf{g m})$ \\
\hline powdered normal pellet diet & $365 \mathrm{~g}$ \\
\hline sheep fat & $310 \mathrm{~g}$ \\
\hline Casein & $250 \mathrm{~g}$ \\
\hline Cholesterol & $10 \mathrm{~g}$ \\
\hline vitamin and mineral mix & $60 \mathrm{~g}$ \\
\hline DL-methionine & $0.3 \mathrm{~g}$ \\
\hline
\end{tabular}




\subsubsection{Animal treatment}

Adult male Wistar albino rats were randomly assigned to the following groups: (1) normal control (NC) group $(\mathrm{n}=10)$; (2) diabetic group (DM); selected on the aforementioned bases $(n=40)$; the second group was randomly divided into two subgroups, (2a) diabetic control rats $(n=20)$ were left without any treatment until the end of the experimental period, and (2b) diabetic rats $(\mathrm{DM}+\mathrm{E}) \quad(\mathrm{n}=20)$ were injected i.p. with exenatide $10 \mu \mathrm{g} / \mathrm{Kg}$ b.w./day (Washington et al., 2010) along for 9 weeks.

\subsubsection{Blood and tissue sampling}

At the end of the $4^{\text {th }}, 6^{\text {th }}, 8^{\text {th }}$ week from STZ injection, animals were fasted for 8 hours, then fasted blood samples were collected from retroorbital plexus of rats under light ether anesthesia using capillary tubes into eppendorf tubes, then centrifuged $\left(600 \mathrm{xg}, 4^{\circ} \mathrm{C}, 15\right.$ minutes $)$ to separate the clear sera, they were analyzed for fasting serum glucose (FSG) and creatinine levels using comm.ercially available Randox reagent kit (Antrim, UK); also serum cystatin-C was determined using enzyme-linked immunosorbent assay (ELISA) kit (RayBio tech Co., USA). At the end of the experimental period, animals were sacrificed by decapitation, blood samples were collected in tubes, centrifuged $\left(600 \mathrm{xg}, 4^{\circ} \mathrm{C}, 15\right.$ minutes) for serum separation, aliquoted for biochemical investigation of FSG, creatinine, cystatin-C, adiponectin, C-peptide, total nitrite/nitrate $\left(\mathrm{NO}_{\mathrm{x}}\right)$ and amylase content/ activity.

For each animal, the kidneys were immediately dissected after sacrificing. They were rinsed with normal saline, dried with filter-paper, and then weighed. The left kidney was homogenized in icecold saline $(20 \% \mathrm{w} / \mathrm{v})$, aliquots of the homogenate were kept at $-70^{\circ} \mathrm{C}$ for subsequent determination of total triglycerides (TGs) and total collagen content; another aliquot of homogenate was mixed with an equal volume of ice-cold $10 \%$ sucrose solution then centrifuged at $1000 \mathrm{xg}$ for 15 minutes at $4^{\circ} \mathrm{C}$, the obtained post-nuclear supernatant was used for determination of glucose-6-phosphatase (G6Pase) enzyme activity. The right kidney was divided transverse into two parts for estimation of G6Pase mRNA gene expression by real time polymerase chain reaction (PCR) and percentage of DNA fragmentation.

\subsubsection{Urine sampling}

Periodic assessment of urinary protein (Upro) was carried out throughout the study (after the $4^{\text {th }}, 6^{\text {th }}$, $8^{\text {th }}$ and $10^{\text {th }}$ week from STZ injection). Six animals from each group were housed individually in metabolic cages for 24-hr urine collection and allowed free access to water only. These samples were centrifuged at $600 \mathrm{xg}$ for 15 minutes at room temperature; the supernatant samples were stored at $-20^{\circ} \mathrm{C}$.

\subsection{Biochemical analysis}

2.4.1 FSG, serum creatinine, amylase, cystatinC, adiponectin, C-peptide and Upro.

Serum glucose was determined by glucose oxidase method (Barham and Trinder, 1972). Serum creatinine was determined according to Bartels et al., (1972). Serum amylase activity was performed kinetically using ELITech kit (France) (Lorentz et al., 1999). Total Upro was estimated according to Orsonneau et al., (1989) method using a commercial kit (LINEAR chemicals, Spain). Serum cystatin- $\mathrm{C}$, adiponectin were performed using a commercially available ELISA kit (ChemiCon international Co., USA), while, serum C-peptide was analyzed by RayBio tech kit (USA).

\subsubsection{Serum $\mathrm{NO}_{\mathrm{x}}$ level}

Nitrite and nitrate are the primary oxidation products of nitric oxide (NO) subsequent to reaction with oxygen and, therefore, the $\mathrm{NO}_{\mathrm{x}}$ concentration in serum was used as an indirect measure of $\mathrm{NO}$ synthesis. $\mathrm{NO}_{\mathrm{x}}$ contents were estimated according to Miranda et al. (2001). Serum samples were deproteinized by methanol/diethylether $\quad(3: 1, \quad \mathrm{v} / \mathrm{v}) \quad$ (sample: methanol/diethylether, 1:9, v/v).( Ghasemi et al., 2007). Quantitation of nitrate and nitrite was based on the Griess reaction, in which a chromophore with a strong absorbance at $550 \mathrm{~nm}$ is formed by reaction of nitrite with a mixture of $\mathrm{N}-(1-\mathrm{Naphthyl})$ ethylenediamine dihydrochloride and sulfanilamide. Any nitrate was reduced to nitrite by vanadium trichloride. $\mathrm{NO}_{\mathrm{x}}$ concentration was calculated by using standard sodium nitrite. Results were expressed as micromoles per liter.

\subsubsection{Renal TGs content}

$20 \%$ of kidney homogenate in ice cold saline was mixed with a (2:1) mixture of chloroform and methanol for lipid extraction so that the purified lipid extract can be obtained by isolating the chloroformic layer as described by Bligh and Dyer (Bligh and Dyer, 1959). The chloroformic phase was further analyzed for TGs content according to McGowan et al. (1983).

\subsubsection{Total renal collagen content}

The renal collagen content was determined by analysis of hydroxy proline (Hp) content according to Reddy and Enwemeka, (1996) method which was based on the alkaline hydrolysis of renal homogenate; followed by oxidation of the free $\mathrm{Hp}$ with chloramine- $\mathrm{T}$ with subsequent addition of Ehrlich's reagent, the chromophore formed was measured colorimetrically at $550 \mathrm{~nm}$.

\subsubsection{G6Pase activity}

The method of Harper was adopted for measuring G6Pase activity (Harper, 1965). It was based on that G6Pase catalyzes the conversion of glucose-6phosphate to glucose and inorganic phosphate, so 
activity of the enzyme was assayed by incubating kidney homogenate with glucose-6-phosphate then stopping the reaction by trichloroacetic acid followed by measuring of inorganic phosphate by the method of Lowry and Lopez (1948). The G6Pase activity was expressed as $\mu$ moles inorganic phosphate/ mg protein / 10 minutes.

\subsubsection{DNA fragmentation}

This method based on that extensively fragmented double-stranded DNA can be separated from chromosomic DNA upon centrifugal sedimentation. The protocol included the lysis of cells and the release of nuclear DNA, a centrifugation step with the generation of two fractions (corresponding to intact and fragmented DNA, respectively), precipitation of DNA, hydrolysis and colorimetrical quantitation upon staining with diphenylamine, which binded to deoxyribose (Boraschi and Maurizi, 1998).

\subsubsection{RNA extraction and real-time PCR analysis for G6Pase}

Total RNA extraction from the right kidney was done using TRIzol (Thermo scientific, USA) according to the manufacturer's instructions. The purity and concentration were determined spectrophotometrically at optical density of 260 and 280 $\mathrm{nm}$ before use. The optical density ratio at 260/280 $\mathrm{nm}$ ranged from 1.7 to 2.0. The isolated total RNA was reverse-transcribed into complementary DNA (cDNA) using the High Capacity cDNA Reverse Transcription Kit (Thermo scientific, USA) according to the manufacturer's instructions and all products were stored at $-20^{\circ} \mathrm{C}$. The expression of target genes was analyzed by qPCR using the SYBR Green PCR Master MIX (Thermo scientific, USA) with the ABI PRISM 7000 sequence detection system (Thermo scientific, USA) and relative quantification software (Thermo scientific, USA). The sequences of the primers used are listed in Table2. Glyceraldehyde-3-phosphate dehydrogenase (GAPDH) was used as the house- eeping gene. The thermal cycle protocol consisting of initial denaturation at $95^{\circ} \mathrm{C}$ for $10 \mathrm{~min}$ followed by 40 cycles with $15 \mathrm{~s}$ denaturation at $95^{\circ} \mathrm{C}$ and $30 \mathrm{~s}$ annealing/extension at $60^{\circ} \mathrm{C}$. As a relative quantitation, fold changes were calculated following the $2^{-\Delta \Delta \mathrm{CT}}$ method (Livak and Schmittgen, 2001). For each sample, the $\mathrm{Ct}$ value of target gene mRNA was normalized to the GAPDH endogenous control as $\Delta \mathrm{Ct}(\Delta \mathrm{Ct}=\mathrm{Ct}$ target gene $\left.-\mathrm{Ct}_{\mathrm{GAPDH}}\right)$. The fold change of the target gene mRNA in the experimental sample relative to control sample was determined by $2^{-\Delta \Delta \mathrm{CT}}$, where $\Delta \Delta \mathrm{CT}=\Delta \mathrm{Ct}_{\text {Experimental }}-\Delta \mathrm{Ct}_{\text {Control }}$.

Table (2) oligonucleotide primers sequence of G6Paset gene and the housekeeping gene.

\begin{tabular}{|c|l|l|l|}
\hline $\begin{array}{c}\text { Gene } \\
\text { name }\end{array}$ & $\begin{array}{l}\text { Gene bank } \\
\text { accession } \\
\text { number }\end{array}$ & Forward primer & Reverse primer \\
\hline G6Pase & {$[$ GenBank } & 5'GACTCACGCG & 5'CATCATGGTGT \\
& : P43428] & GAACCTTTAT3' & GACCTCTGTAG3' \\
\hline GAPDH $\$$ & {$[$ GenBank: } & 5'AACAGCAACT & 5'TGGGTGCA \\
& M17701] & CCCACTCTTC3' & GCGAACTTTAT3' \\
\hline
\end{tabular}

†: glucose-6-phosphatase; $\$$ : glyceraldehyde-3-phosphate dehydrogenase.

\subsection{Statistical analysis}

All data were reported as means \pm SE. Differences between groups were examined for statistical significance using one-way analysis of variance (ANOVA), followed by Tukey multiple comparison test. A $P$ value $<0.05$ denoted the presence of a statistically significant difference. All statistical analysis was done using Graph Pad Prism, version 5.01 (Graph Pad Software, La Jolla, CA, USA).

\section{Results}

3.1 Serum glucose, cystatin- $C$, creatinine and urinary protein

The changes of biochemical parameters at different time intervals in various groups are shown in Fig. (1).

At each time point, FSG in the DM group was significantly higher than that in the $\mathrm{NC}$ group $(\mathrm{P}<0.05)$. In the DM group, serum cystatin $\mathrm{C}$ and Upro began to rise from the $4^{\text {th }}$ week of STZ injection and reached a maximum at $10^{\text {th }}$ week; there were statistically significant differences between $\mathrm{DM}$ and NC groups $(\mathrm{P}<0.05)$ Compared to the control group, the level of serum creatinine began to increase significantly at $6^{\text {th }}$ week after STZ injection $(\mathrm{P}<0.05)$ showed a gradually increasing trend until completing the study. Our results showed that exenatide administration for 3 and 5 weeks significantly decreased FSG compared with NC group, whereas it was almost normalized at 7 and 9 weeks of administration. The effect of exenatide administration on serum creatinine and cystatin $\mathrm{C}$ appeared after 5 weeks of administration where exenatide nearly normalized both of them, the effect which proceeded along the period of the study $(\mathrm{P}<0.05)$. Regarding Upro; exenatide also exerted a significant improving effect $(\mathrm{P}<0.05)$ along the period of the study Fig. (1).

\subsection{Serum adiponectin, amylase, $\mathrm{C}$-peptide and total $\mathrm{NO}_{\mathrm{x}}$}

As shown in Fig. (2), DM rats exhibited a marked reduction in serum adiponectin, an insulin sensitizer, by $23 \%$ from normal control value $(\mathrm{P}<0.05)$, an effect that was abolished by exenatide in $\mathrm{DM}+\mathrm{E}$ group after 9 weeks of treatment $(\mathrm{P}<0.05)$. At the end of the experiment no significant change in serum amylase activity was noticed either in DM or $\mathrm{DM}+\mathrm{E}$ rats with respect to the normal control rats. DM rats exhibited significant reduction in serum C- 
peptide level reaching $35 \%$ of the normal value $(\mathrm{P}<0.05)$. Whereas, administration of exenatide for 9 weeks significantly increased serum C-peptide level 2.6 times the corresponding diabetic control $(\mathrm{P}<0.05)$ with no significant difference compared to the normal value. Regarding serum $\mathrm{NO}_{\mathrm{x}}$, diabetes caused $30 \%$ reduction in serum $\mathrm{NO}_{\mathrm{x}}$ from normal values $(\mathrm{P}<0.05)$, an effect which was significantly ameliorated by exenatide administration in $\mathrm{DM}+\mathrm{E}$ group as indicated by $24 \%$ increase in serum $\mathrm{NO}_{\mathrm{x}}$ level comparing to the diabetic rats.

\subsection{Renal glucose-6- phosphatase (G6Pase)}

Figure (3) illustrates the boosting effect of the current T2DM model on G6Pase activity (1.7 folds) and expression ( 6 folds) in the renal tissues after 10 weeks of induction $(\mathrm{P}<0.05)$. This effect on the enzyme activity was significantly hindered in $\mathrm{DM}+\mathrm{E}$ group $(\mathrm{P}<0.05)$, whereas, the mRNA expression of the enzyme was significantly reduced after 9 weeks of exenatide treatment $(\mathrm{P}<0.05)$ but without reaching the normal expression level $(\mathrm{P}<0.05)$.

\subsection{Renal DNA fragmentation}

A dramatic increase in percentage of renal DNA fragmentation was revealed in the DM group (6.5 folds) compared with the $\mathrm{NC}$ one $(\mathrm{P}<0.05)$, however, exenatide treatment showed significant improvement in renal DNA fragmentation $(\mathrm{P}<0.05)$ which still significant from normal values $(\mathrm{P}<0.05)$ [Figure (3), (4)].

\subsection{Renal TGs content}

The data presented in Fig. (3) depicted the marked elevation of renal TGs content in DM group reaching 3.5 folds the $\mathrm{NC}$ values $(\mathrm{P}<0.05)$. On the other hand, $\mathrm{DM}+\mathrm{E}$ group exhibited significant reduction in the elevated renal TGs content amounting to $44 \%$ of the DM group $(\mathrm{P}<0.05)$, however, such reduction by exenatide was not enough to normalize renal TGs content $(\mathrm{P}<0.05)$.

\subsection{Renal Hp content}

Our results demonstrated the intensified $\mathrm{Hp}$ production, an indicator of fibrosis, in renal tissues of DM group, 10 weeks after STZ injection, $(\mathrm{P}<0.05)$. Exenatide injection in $\mathrm{DM}+\mathrm{E}$ group overrides Hp production approaching the normal control values $(\mathrm{P}<0.05)$ [Figure $(3)]$.

\section{Discussion}

$\mathrm{DN}$ is a serious microvascular complication that affects a significant proportion of patients suffering from both T1DM and T2DM, accounting for over $40 \%$ of ESRD cases (De Zeeuw et al., 2006). In the present study we evaluated the role of GLP-1R activation using the GLP-1R agonist, exenatide, in ameliorating the progression of $\mathrm{DN}$ in a model of T2DM in rats.T2DM was induced in rats by feeding HFD and low dose STZ injection, a model which is characterized by obesity, hyperglycemia and insulin resistance followed by $\beta$-cell dysfunction, a state that closely resembles the metabolic abnormalities occur in patients with T2DM (Luo et al., 1998). Our model showed frank hyperglycemia associated with impaired GFR and renal excretory functions as well as changes in some renal biochemical parameters.

The hyperglycemia observed in our study could be explained through Randle or glucose-fatty acid (FA) cycle (Randle et al., 1963); as the preferential use of increased FAs for oxidation blunts the insulin-mediated reduction of hepatic glucose output and reduces the glucose uptake or utilization in skeletal muscle (Belfiore and Iannello, 1998). Our results revealed relative insulin deficiency documented by low serum C-peptide levels at the end of the study, as a reflection of pancreatic secretion; this finding comes in parallel with Hao et al., (2013), results. Elevated free FA together with glucotoxicity, induced by prolonged hyperglycemia, were previously reported to negatively impact $\beta$-cell functions and altering $\beta$-cell mass (ChangChen et al., 2008).

Exenatide treatment significantly normalized blood glucose levels within 7 weeks of treatment; this finding goes in line with the recorded data by Fan et al., (2008). The glucose-lowering effect of exenatide was associated with significant increase in serum C-peptide level; this result is consistent with previously published literature (Bunck et al., 2011). Based on these previous and our present findings, we suggested that exenatide glucoregulatory action takes place through the stimulation of pancreatic $\beta$-cell secretion (Fehmann and Habener, 1992), $\beta$-cell regeneration and consequent augmented $\beta$-cell function (Fehmann and Habener, 1992). GLP-1 stimulates glucose-dependent insulin secretion via activation of its specific $G$ proteincoupled receptor GLP-1R on islet $\beta$-cells (Drucker, 2006). Engagement of the GLP-1R stimulates cAMP formation and activation of downstream pathways coupled to protein kinase A (PKA) (Holz, 2004), GLP-1R activation is also coupled to increased intracellular calcium, inhibition of voltage-dependent $\mathrm{K}^{+}$channels and activation of phosphateidylinositol-3-kinase (PI3K) (Drucker, 2006). In Addition, binding of exenatide to GLP$1 \mathrm{R}$ on islet $\alpha$-cells lowers the blood glucose via inhibition of glucagon secretion (Li et al., 2005). Another mechanism explained by Sancho et al., (2005) showed that the normoglycemic effect of exenatide may be due to the normalization of insulin signaling pathway and glucose transport through increasing the expression of insulin receptor substrate- 1 and glucose transporter- 4 as a result of GLP-1R activation in adipocytes.

Our observations showed elevated renal G6Pase mRNA expression and activity in DM group, which might be related to the state of insulin deficiency resulting in reduction of insulin- 
suppressed renal glucose release as discussed by Gerich, (2010). Exenatide treatment significantly reduced renal G6Pase expression and activity, which may be due to restoration of insulin secretion as revealed by the observed normalized C-peptide level. On the other hand it was proposed that exendin-4 treatment inhibits G6Pase expression in hepatocytes of young adult normal nondiabetic mice through $\mathrm{PKB} / \mathrm{Akt}$ activation followed by Forkhead Box protein O1 (FOXO1) deactivation, (Fan et al., 2008) since FOXO1 positively regulates G6Pase transcription (Zhang et al., 2006). This suggestion could add to the glucose lowering effect of exenatide. To our knowledge, this is the first observation of the effect of exenatide on renal gluconeogenic enzyme.

Impaired GFR and renal excretory functions were mirrored in our study by significantly elevated serum creatinine as well as proteinuria in DM group, these findings were in consistent with the study of Luo et al., (2006). As a result of the insensitivity of serum creatinine to small or moderate decrease in GFR "creatinine blind GFR area", we investigated the most sensitive serum cystatin $\mathrm{C}$ level which showed prompt elevation in diabetic rats indicating early renal injury. The present study was the first to address this result in STZ-HFD- induced DN model. Elevated blood cystatin $\mathrm{C}$ with the profound increment in Upro excretion suggest greater permeability of the glomerular basement membrane network caused by increased level of protein glycosylation as a result of hyperglycemia (Yokozawa et al., 2001). There was also a growing body of evidence that AGEs and their receptor RAGE interaction elicits oxidative stress, inflammatory reactions and thrombosis, thereby being involved in vascular aging and damage in DM (Yamagishi, 2011) where AGEs induce apoptotic cell death and expression of both vascular endothelial growth factor and monocyte chemoattractant protein-1 in mesangial cells (Yamagishi et al., 2007), as well, it stimulates insulin-like growth factor-I, -II, platelet derived growth factor and transforming growth factor- $\beta$ (TGF- $\beta$ ) in mesangial cells, which in turn mediate production of type IV collagen, laminin and fibronectin (Yamagishi et al., 2007 and Fukami, et al., 2004). AGEs induce TGF- $\beta$ overexpression in both podocytes and proximal tubular cells (Yamagishi et al., 2007). Non-enzymatic glycations of type IV collagen and laminin reduce their ability to interact with negatively charged proteoglycans, increasing vascular permeability to albumin. Furthermore, impair the degradation of matrix proteins by matrix metaloproteinases, contributing to basement membrane thickening and mesangial expansion, hallmarks of DN (Yamagishi et al., 2007).

In concomitant with Kodera et al., (2011) exenatide treatment in the present study significantly ameliorated serum creatinine and proteinuria, as well as serum cystatin $\mathrm{C}$ decreasing the severity of $\mathrm{DN}$.
This could be mainly through improvement in the glycemic control, in addition, serum C-peptide was reported to improve renal function and reduce urinary albumin excretion in T1DM patients (Fernqvist-Forbes et al., 2001), second assumption is that exenatide could block the AGE signaling in mesangial cells through GLP-1R activation which inhibit AGE-induced vascular cell adhesion molecule-1 mRNA levels in mesangial cells (Ishibashi et al., 2010).

In our observation the DM rats showed elevated renal TGs. This came in agreement with several studies which have shown that lipid accumulation was observed in the kidneys of diabetic experimental animals (Proctor et al., 2006) and humans (Lee and Kruth, 2003). Increased renal accumulation of lipids in diabetic rats may be mediated through hyperglycemia induced renal expression of sterol regulatory element-binding protein-1 which causes an increase in FA synthesis and accumulation of neutral fat in renal cells (Jiang et al., 2005). Exenatide treatment, in our study, significantly ameliorated lipid deposits in the kidney of diabetic rats; this finding was in agreement with Park et al., (2007). This may be related to GLP-1R activation which results in enhanced peroxisome proliferator-activated receptor- $\alpha$ expression in the kidney leading to decreased renal lipid accumulation, as peroxisome proliferator-activated receptor- $\alpha$ is responsible for inducing mitochondrial and peroxisomal FA $\beta$-oxidation (Park et al., 2007).

Our DN model showed significantly hypoa-diponectinemia which consented with (Hotta et al., 2001). Hypoadiponectinemia may be due to down regulation of adiponectin receptors, AdipoR1 and AdipoR2, which mediate the antidiabetic metabolic actions of adiponectin, as well as reduction in adiponectin expression as shown in insulinresistant rodent models ( $\mathrm{Hu}$ et al., 1996). Decreased adipocyte PI3K activity, a major intermediate of insulin signaling activity, in T2DM patients may contribute to the decreased serum adiponectin levels, where Bogan and Lodish, (1999) have shown that PI3K, is essentially required for the secretion of adiponectin by adipocytes. Exenatide administration to diabetic rats resulted in significant increase in serum adiponectin level, this result was in line with Li et al., (2008), who reported that exenatide exerted its action through turning on the PKA-, PI3K-dependent pathways. The present DN model showed a dramatic increase in the percentage of renal DNA fragmentation; an additional apoptotic renal injury to the previously reported measures. It was reported that hyperglycemia, induced by glucose loading, led to DNA fragmentation in the DNA of proximal tubular cells (Ishii et al., 1966) due to induction of oxidative stress (Allen et al., 2003). Exenatide showed anti-apoptotic effect as revealed by significant reduction in renal DNA fragmentation; this 
might involve releasing of cAMP with subsequent activation of PI3K and its downstream PKB/Akt and PKA signal transduction pathways ( $\mathrm{Li}$ et al., 2013). Also the reduction of apoptosis factor; caspase 3 and apoptosis promoting genes accompanied by the regulation of the expression of antiapoptotic proteins e.g. Bcl-2 as proposed by Li et al., (2013) could be involved. The possible antiapoptotic effect mediated by exenatide in this model was first demonstrated.

A significant increase in the levels of renal $\mathrm{Hp}$ content, a marker for collagen deposition, was observed in DM rats; this increase reflects the severity of the kidney lesions and fibrosis in these rats. Previous studies demonstrated that hyperglycemia-induced multiple cell metabolic disorder signals, including activation of PKC, whereas, abnormal activation of PKC contributes to increased microvascular matrix protein (collagen and fibronectin) accumulation, (Kanwar et al., 2008) as well as increasing macrophages infil-tration to the kidney that causes stimulation of mesangial cells to produce fibronectin (Pawluczyk and Harris, 1997) also directly increases in the secretion of TGF- $\beta$ (Leonarduzzi et al., 1997( which play a central role in the enhancement of glomerular extracellular matrix production in DN (Ziyadeh et al., 2000).

Exenatide treatment effectively diminished the kidney collagen accumulation as reflected by normalized kidney Hp level, suggesting its antifibrotic efficacy in diabetic condition. This result is consistent with previously published literature (Gou et al., 20104), which proposed that this effect is due to exenatide anti-inflammatory properties through reduction in renal TGF- $\beta 1$ content and inhibition of nuclear factor kappa-B activity.

The present DN model showed decreased serum $\mathrm{NO}_{\mathrm{x}}$ as compared to normal rats, this result agree with Arya et al., (2001). It was reported also that renal eNOS production has been decreased in prolonged DM (Prabhakar et al., 2007). Several mechanisms contribute to the loss of NO homeostasis, including hyperglycemia, insulin resistance, and free FA production (Modlinger et al., 2004). In our study, prolonged treatment with exenatide augmented NO production, this result agreed with that of Sélley et al., (2014). Such effect may be due to GLP-1-mediated enhanced eNOS phosphorylation/NO production, which is dependent on the activation of the PI3K-PKB pathway (Erdogdu et al., 2010).

In our study there was no pancreatitis observed in $\mathrm{DM}+\mathrm{E}$ group, the result which is coherent to Taylor et al., (2011).

\section{Conflict of interest}

All authors of this manuscript declare that, they have no conflict of interest in relation to this manuscript.

\section{Conclusion}

In conclusion, our study revealed the strength of exenatide in preventing diabetic nephropathy and its broad improving effect through several aspects, demonstrating the inhibition of renal DNA fragmentation and gluconeogenesis. 

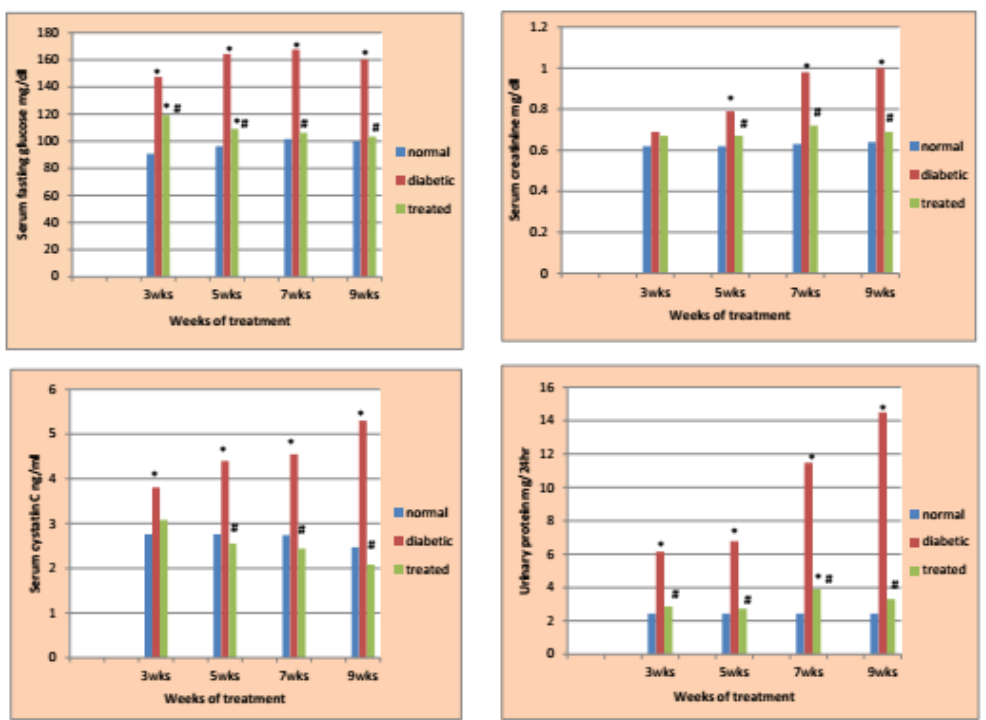

Figure (1) changes in biochemical parameters at different time intervals along the study: Mean changes in (A) fasting serum glucose level (FSG) (B) serum cystatin C, (C) serum creatinine and (D) urinary protein (Upro) in (HFD-STZ)-induced diabetic rats treated with exenatide. Exenatide was administered i.p. daily in a dose of $10 \mu \mathrm{g} / \mathrm{Kg}$ b.w after one week from STZ injection along for 9 weeks. Data are expressed as mean \pm S.E. ${ }^{*}:$ significant difference from normal control at $\mathrm{P}<0.05$. " : significant difference from diabetic rats at $\mathrm{P}<0.05$ (one-way ANOVA followed by Tukey Multiple Comparison Test).

NC: normal control; DM: diabetic rats; DM+E: diabetic rats treated with exenatide.
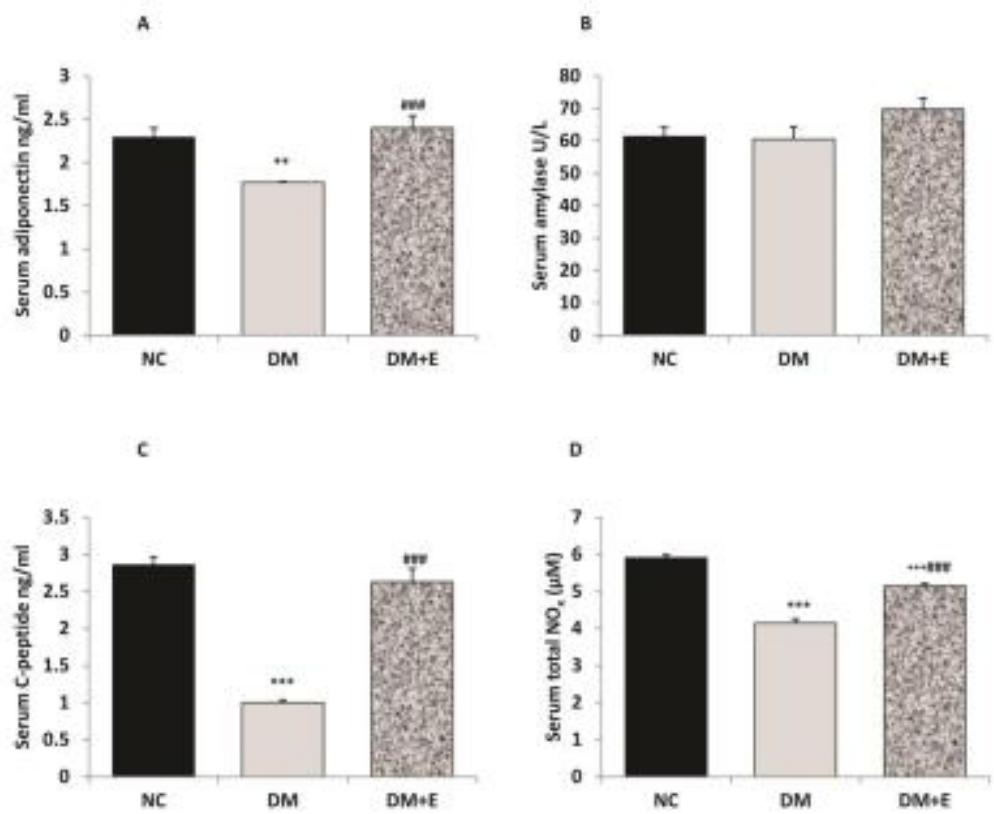

Figure (2) changes in serum parameters at the end of the study: Mean changes in serum (A) adiponectin, (B) amylase, (C) C-peptide and (D) total nitrite/nitrate $\left(\mathrm{NO}_{\mathrm{x}}\right.$ ) levels in (HFD-STZ)-induced diabetic rats treated with exenatide. Exenatide was administered i.p. daily in a dose of $10 \mu \mathrm{g} / \mathrm{Kg}$ b.w after one week from STZ injection along for 9 weeks. Data are expressed as mean \pm S.E. ${ }^{* * * * *}$ : significant difference

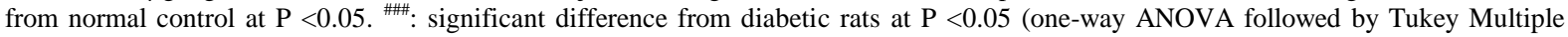
Comparison Test). NC: normal control; DM: diabetic rats; DM+E: diabetic rats treated with exenatide. 

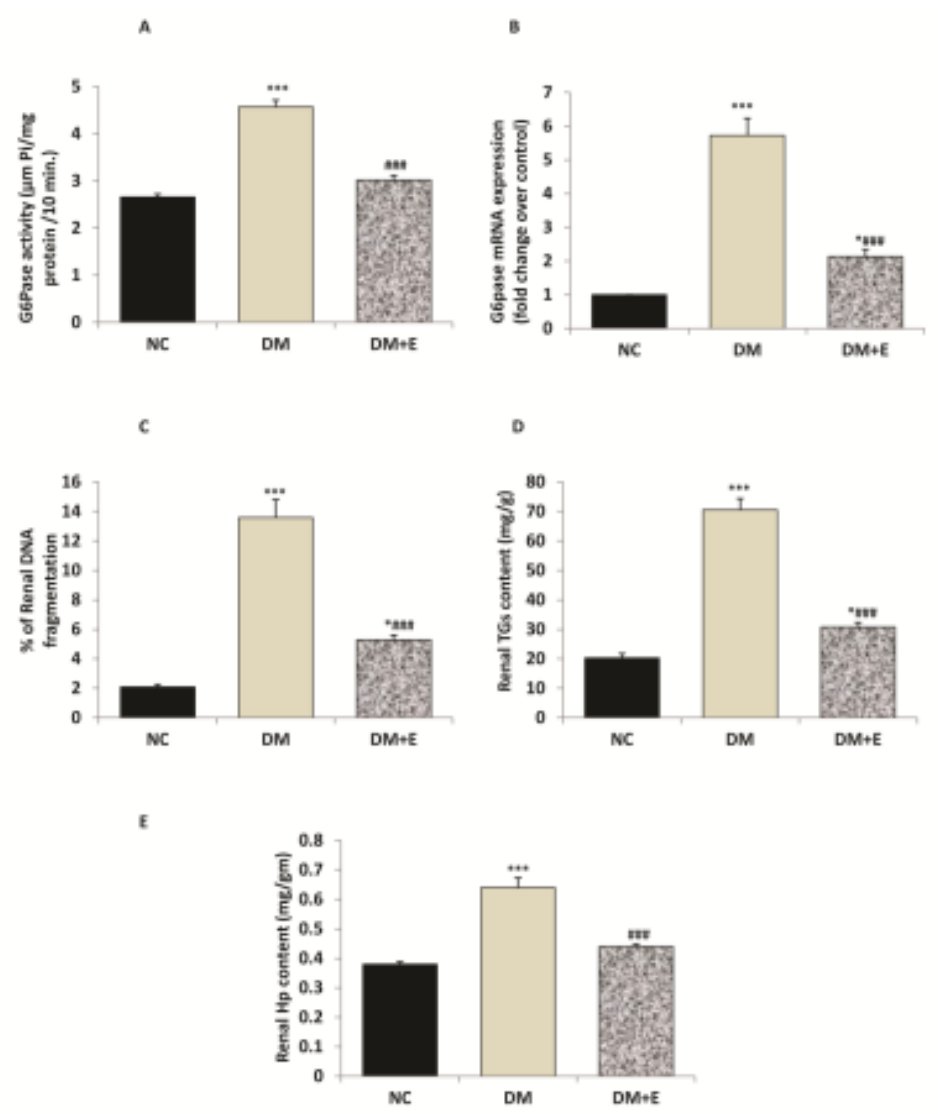

Figure (3) changes in renal parameters at the end of the study: Mean changes in renal: (A) G-6 phosphatase (G6Pase) activity, (B) G-6 phosphatase mRNA expression, (C) DNA fragmentation, (D) triglycerides (TGs) and (E) hydroxy proline (Hp) contents in (HFD-STZ)induced diabetic rats treated with exenatide. Exenatide was administered i.p. daily in a dose of $10 \mu \mathrm{g} / \mathrm{Kg}$ b.w after one week from STZ injection along for 9 weeks. Data are expressed as mean \pm S.E. ${ }^{*}, * * *$ : significant difference from normal control at $\mathrm{P}<0.05$. ${ }^{\# \# !}$ : significant difference from diabetic rats at $\mathrm{P}<0.05$ (one-way ANOVA followed by Tukey Multiple Comparison Test).

NC: normal control; DM: diabetic rats; DM+E: diabetic rats treated with exenatide, Pi; inorganic phosphate.

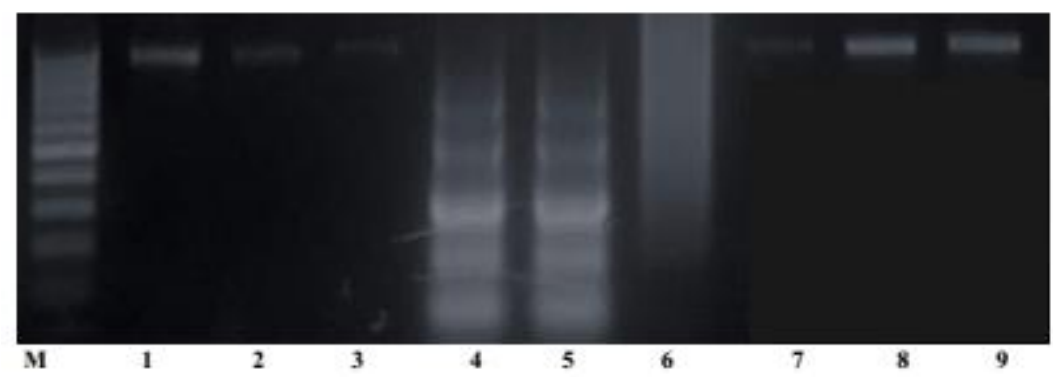

Figure (4): Renal DNA fragmentation on agarose gel electrophoresis: Lane M: represents DNA marker with 100bp, Lane 1, 2 and 3 DNA isolated from kidney homogenate of normal rats, Lane 4, 5 and 6: DNA isolated from kidney homogenate of diabetic rats (induced by HFD-STZ) and Lane 7, 8 and 9: DNA isolated from kidney homogenate of exenatide treated rats; exenatide was administered i.p. daily in a dose of $10 \mu \mathrm{g} / \mathrm{Kg}$ b.w after one week from STZ injection along for 9 weeks. 


\section{$\underline{\text { References }}$}

Allen DA, Harwood S, Varagunam M, Raftery MJ, Yaqoob MM. High glucose-induced oxidative stress causes apoptosis in proximal tubular epithelial cells and is mediated by multiple caspases. FASEB J 2003; 17(8): 908-910.

Arya A, Yadav HN, Sharma PL. Involvement of vascular endothelial nitric oxide synthase in development of experimental diabetic nephropathy in rats. Mol. Cell. Biochem 2011; 354(1-2): 57-66.

Badran M, Laher I. Type II diabetes mellitus in Arabicspeaking countries. Int. J. Endocrinol 2012; 2012: 1-11.

Barham D, Trinder P. An improved colour reagent for the determination of blood glucose by the oxidase system. Analyst 1972; 97(151): 142-145. doi: 10.1039/AN9729700142

Bartels H, Böhmer M, Heierli C. Serum creatinine determination without protein precipitation. Clin. Chim. Acta 1972; 37: 193-197.

Belfiore F, Iannello S. Insulin resistance in obesity: metabolic mechanisms and measurement methods. Mol. Genet. Metab 1998; 65(2): 121-128.

Bligh EG, Dyer WJ. Extraction of Lipids in Solution by the Method of Bligh \& Dyer. Can. J. Biochem. Physiol 1959; 2(37): 911-917.

Bogan JS, Lodish HF. Two compartments for insulinstimulated exocytosis in 3T3-L1 adipocytes defined by endogenous ACRP30 and GLUT4. J. Cell Biol. 1999; 146(3): 609-620.

Boraschi, D. and Maurizi, G. Quantitation of DNA fragmentation with diphenylamine. In Apoptosis-a Laboratory Manual of Experimental Methods, Cossarizz A, Boraschi D, (eds.); GCI Publications: L’Aquila 1998; 153-161.

Bullock BP, Heller RS, Habener JF. Tissue distribution of messenger ribonucleic acid encoding the rat glucagon-like peptide-1 receptor. Endocrinology 1996; 137(7): 2968-2978.

Bunck MC, Cornér A, Eliasson B. Effects of exenatide on measures of $\beta$-cell function after 3 years in metformin-treated patients with type 2 diabetes. Diabetes Care 2011; 34(9): 20412047.

Chang-Chen KJ, Mullur R, Bernal-Mizrachi E. Beta-cell failure as a complication of diabetes. Rev. Endocr. Metab. Disord 2008; 9(4): 329-343.

De Zeeuw D, Parving H-H, Henning RH. Microalbuminuria as an early marker for cardiovascular disease. J. Am. Soc. Nephrol 2006; 17(8): 2100-2105.

Drucker DJ. The biology of incretin hormones. Cell Metab 2006; 3(3):153-165.

Erdogdu O, Nathanson D, Sjöholm A, Nyström T, Zhang Q. Exendin-4 stimulates proliferation of human coronary artery endothelial cells through eNOS-, PKA- and PI3K/Aktdependent pathways and requires GLP-1 receptor. Mol. Cell. Endocrinol 2010; 325(1-2): 26-35.

Fan R, Kang Z, He L, Chan J, Xu G. Exendin-4 improves blood glucose control in both young and aging normal nondiabetic mice, possible contribution of beta cell independent effects. PLoS One 2011; 6(5): e20443.

Fehmann HC, Habener JF. Insulinotropic hormone glucagonlike peptide-I(7-37) stimulation of proinsulin gene expression and proinsulin biosynthesis in insulinoma beta TC-1 cells. Endocrinology 1992; 130(1): 159-166.

Fernqvist-Forbes E, Johansson BL, Eriksson MJ. Effects of C-peptide on forearm blood flow and brachial artery dilatation in patients with type 1 diabetes mellitus. Acta Physiol. Scand 2001; 172(3): 159-165.

Fowler MJ. Microvascular and macrovascular complications of diabetes. Clinical Diabetes 2008; 26(2): 77-82.

Fukami K, Ueda S, Yamagishi S. AGEs activate mesangial TGF-beta-Smad signaling via an angiotensin II type I receptor interaction. Kidney Int 2004; 66(6): 2137-2147.

Gedulin BR, Nikoulina SE, Smith PA. Exenatide (exendin-4) improves insulin sensitivity and \{beta\}-cell mass in insulinresistant obese fa/fa Zucker rats independent of glycemia and body weight. Endocrinology 2005; 146(4): 2069-2076.
Gerich JE. Role of the kidney in normal glucose homeostasis and in the hyperglycaemia of diabetes mellitus: therapeutic implications. Diabet. Med 2010; 27(2):136-42.

Ghasemi A, Hedayati M, Biabani H. Protein precipitation methods evaluated for determination of serum nitric oxide end products by the Griess Assay. Jmsr 2007;1(2):29-32.

Gou S, Zhu T, Wang W, Xiao M, Wang X, Chen Z. Glucagon like peptide-1 attenuates bleomycin-induced pulmonary fibrosis, involving the inactivation of $\mathrm{NF}-\kappa \mathrm{B}$ in mice. Int. Immunopharmacol 2014; 22(2): 498-504.

Hao H, Liu J, Shen J. Multiple intravenous infusions of bone marrow mesenchymal stem cells reverse hyperglycemia in experimental type 2 diabetes rats. Biochem. Biophys. Res. Commun 2013; 436(3): 418-423.

Harper AE. 1965. Measurement of enzyme activity: Glucose-6phosphatase. In Methods of enzymatic analysis, Bergmeyer HU (ed.); Academic Press: New York; 788-792.

Holz GG. Epac: A New cAMP-Binding Protein in Support of Glucagon-like Peptide-1 Receptor-Mediated Signal Transduction in the Pancreatic $\beta$-cell. Diabetes 2004; 53(1): 513.

Hotta K, Funahashi T, Bodkin NL, Circulating concentrations of the adipocyte protein adiponectin are decreased in parallel with reduced insulin sensitivity during the progression to type 2 diabetes in rhesus monkeys. Diabetes 2001; 50(5): 1126-1133.

Hu E, Liang P, Spiegelman BM. AdipoQ is a novel adiposespecific gene dysregulated in obesity. J. Biol. Chem 1996; 271(18): 10697-10703

Ishibashi Y, Matsui T, Takeuchi M, Yamagishi S-I. Glucagon-like peptide-1 (GLP-1) inhibits advanced glycation end product (AGE)-induced up-regulation of VCAM-1 mRNA levels in endothelial cells by suppressing AGE receptor (RAGE) expression. Biochem. Biophys. Res. Commun 2010; 391(3): 1405-1408.

Ishii N, Ogawa Z, Suzuki K, Numakami K, Saruta T, Itoh H. Glucose loading induces DNA fragmentation in rat proximal tubular cells. Metabolism 1996; 45(11): 1348-1353.

Jiang T, Liebman SE, Lucia MS, Phillips CL, Levi M. Calorie restriction modulates renal expression of sterol regulatory element binding proteins, lipid accumulation, and age-related renal disease. J. Am. Soc. Nephrol 2005; 16:238594.

Kanwar YS, Wada J, Sun L. Diabetic nephropathy: mechanisms of renal disease progression. EBM 2008; 233: 411.

Keane WF. The role of lipids in renal disease: Future challenges. Kidney Int 2000; 57(s75): 27-31.

Klonoff DC, Buse JB, Nielsen LL. Exenatide effects on diabetes, obesity, cardiovascular risk factors and hepatic biomarkers in patients with type 2 diabetes treated for at least 3 years. Curr. Med. Res. Opin 2008; 24(1): 275-286.

Kodera R, Shikata K, Kataoka HU. Glucagon-like peptide-1 receptor agonist ameliorates renal injury through its antiinflammatory action without lowering blood glucose level in a rat model of type 1 diabetes. Diabetologia 2011; 54(4): 965978.

Lee HS, Kruth HS. Accumulation of cholesterol in the lesions of focal segmental glomerulosclerosis. Nephrology (Carlton) 2003; 8(5): 224-223

Leonarduzzi G, Scavazza A, Biasi F. The lipid peroxidation end product 4-hydroxy-2,3-nonenal up-regulates transforming growth factor beta1 expression in the macrophage lineage: a link between oxidative injury and fibrosclerosis. FASEB J 1997; 11(11): 851-857.

Li Y, Cao X, Li LX, Brubaker PL, Edlund H, Drucker DJ. $\beta$-cell Pdx1 expression is essential for the glucoregulatory, proliferative, and cytoprotective actions of glucagon-like peptide-1. Diabetes 2005; 54(2): 482-491.

Li Z, Zhou Z, Huang G, Hu F, Xiang Y, He L. Exendin-4 protects mitochondria from reactive oxygen species induced apoptosis in pancreatic Beta cells. PLoS One 2013; 8(10): e76172. 
Li, L., Yang, G., Li, Q., Tan, X., Liu, H., Tang, Y. and Boden. G. Exenatide prevents fat-induced insulin resistance and raises adiponectin expression and plasma levels. Diabetes. Obes. Metab 2008; 10(10): 921-930.

Lin C-Y, Chen M-F, Lin L-Y, Liau C-S, Lee Y-T, Su T-C. Insulin resistance is the major determinant for microalbuminuria in severe hypertriglyceridemia: Implication for high-risk stratification. Intern. Med 2008; 47(12): 1091-1097.

Livak KJ, Schmittgen TD. Analysis of relative gene expression data using real-time quantitative PCR and the 2(Delta Delta C(T)) Method. Methods 2001; 25(4): 402-408.

Lorentz K, Gütschow B, Renner F. Evaluation of a direct alpha-amylase assay using 2-chloro-4-nitrophenyl-alpha-Dmaltotrioside. Clin. Chem. Lab. Med 1999; 37(11-12): 10531062.

Lowry OH, Lopez JA. The Determination of inorganic phosphate in the presence of phosphate esters. J. Biol. Chem 1946; 162(3): 421-428.

Luo J, Quan J, Tsai J. Nongenetic mouse models of noninsulin-dependent diabetes mellitus. Metabolism 1998; 47(6): 663-668

Luo P, Zhou Y, Chang H-H. Glomerular 20-HETE, EETs, and TGF-beta1 in diabetic nephropathy. Am. J. Physiol. Renal Physiol 2009; 296(3): F556-563.

McGowan MW, Artiss JD, Strandbergh DR, Zak B. A peroxidase-coupled method for the colorimetric determination of serum triglycerides. Clin. Chem 1983; 29(3): 538-542.

Meier JJ, Gallwitz B, Schmidt WE, Nauck MA. Glucagonlike peptide 1 as a regulator of food intake and body weight: therapeutic perspectives. Eur. J. Pharmacol 2002; 440(2-3): 269-279

Miranda KM, Espey MG, Wink D. A rapid, simple spectrophotometric method for simultaneous detection of nitrate and nitrite. Nitric Oxide 2001; 5(1): 62-71.

Modlinger PS, Wilcox CS, Aslam S. Nitric oxide, oxidative stress, and progression of chronic renal failure. Semin. Nephrol 2004; 24(4): 354-365.

Mogensen CE. The Kidney and Hypertension in Diabetes Mellitus; 3rd edition; Kluwer Academic Publishers: Boston, 1997; 397-403.

Nikolaidis LA, Mankad S, Sokos GG, Miske G, Shah A, Elahi D, Shannon RP. Effects of glucagon-like peptide-1 in patients with acute myocardial infarction and left ventricular dysfunction after successful reperfusion. Circulation 2004; 109(8): 962-965

Obineche EN, Adem A. Update in Diabetic Nephropathy. Int J Diabetes \& Metabolism 2005; 13: 1-9.

Orsonneau J, Douet P, Massoubre C, Lustenberger P, Bernard S. An improved pyrogallol red-molybdate method for determining total urinary protein. Clin. Chem. 1989;35(11):2233-2236.

Park CW, Kim HW, Ko SH Long-term treatment of glucagonlike peptide-1 analog exendin-4 ameliorates diabetic nephropathy through improving metabolic anomalies in $\mathrm{db} / \mathrm{db}$ mice. J. Am. Soc. Nephrol 2007; 18(4): 1227-1238.

Pavenstädt H, Kriz W, Kretzler M. Cell biology of the glomerular podocyte. Physiol. Rev 2003; 83(1): 253-307.

Pawluczyk IZ, Harris KP. Macrophages promote prosclerotic responses in cultured rat mesangial cells: a mechanism for the initiation of glomerulosclerosis. J. Am. Soc. Nephrol 1997; 8(10): 1525-1536.

Prabhakar S, Starnes J, Shi S, Lonis B, Tran R. Diabetic nephropathy is associated with oxidative stress and decreased renal nitric oxide production. J. Am. Soc. Nephrol 2007; 18(11): 2945-2952.

Proctor G, Jiang T, Iwahashi M, Wang Z, Li J, Levi M. Regulation of renal fatty acid and cholesterol metabolism, inflammation, and fibrosis in Akita and OVE26 mice with type 1 diabetes. Diabetes 2006; 55(9): 2502-2509.

Pucci L, Triscornia S, Lucchesi D. Cystatin C and estimates of renal function: searching for a better measure of kidney function in diabetic patients. Clin. Chem 2007; 53(3): 480-488.

Randle PJ, Garland PB, Hales CN, Newsholme EA. The glucose fatty-acid cycle. Its role in insulin sensitivity and the metabolic disturbances of diabetes mellitus. Lancet 1963; 1(7285): 785-789.

Reddy GK, Enwemeka CS. A simplified method for the analysis of hydroxyproline in biological tissues. Clin. Biochem 1996; 29(3): 225-229.

Riddle MC, Henry RR, Poon TH. Exenatide elicits sustained glycaemic control and progressive reduction of body weight in patients with type 2 diabetes inadequately controlled by sulphonylureas with or without metformin. Diabetes. Metab. Res. Rev 2006; 22(6): 483-491.

Sahin K, Onderci M, Tuzcu M. Effect of chromium on carbohydrate and lipid metabolism in a rat model of type 2 diabetes mellitus: the fat-fed, streptozotocin-treated rat. Metabolism 2007; 56(9): 1233-1240.

Sancho V, Trigo M V., González N, Valverde I, Malaisse WJ, Villanueva-Peñacarrillo ML. Effects of glucagon-like peptide-1 and exendins on kinase activity, glucose transport and lipid metabolism in adipocytes from normal and type-2 diabetic rats. J. Mol. Endocrinol 2005; 35(1): 27-38.

Sélley E, Kun S, Szijártó IA. Exenatide induces aortic vasodilation increasing hydrogen sulphide, carbon monoxide and nitric oxide production. Cardiovasc. Diabetol 2014; 13:69. Shlipak M. Diabetic nephropathy. BMJ Clin. Evid 2009; 01: 0606.

Taylor K, Gurney K, Han J, Pencek R, Walsh B, Trautmann M. Exenatide once weekly treatment maintained improvements in glycemic control and weight loss over 2 years. BMC Endocrine Disorders 2011; 11: 1-9.

Thorens B. Expression cloning of the pancreatic beta cell receptor for the gluco-incretin hormone glucagon-like peptide 1 . Proc. Natl. Acad. Sci. U. S. A 1992; 89(18): 8641-8645.

Tuttle KR, Anderson PW. A novel potential therapy for diabetic nephropathy and vascular complications: protein kinase C beta inhibition. Am. J. Kidney Dis 2003; 42(3): 456-465. Washington MC, Raboin SJ, Thompson W, Larsen CJ, Sayegh AI. Exenatide reduces food intake and activates the enteric nervous system of the gastrointestinal tract and the dorsal vagal complex of the hindbrain in the rat by a GLP-1 receptor. Brain Res 2010; 1344: 124-133.

Yamagishi S, Fukami K, Ueda S, Okuda S. Molecular mechanisms of diabetic nephropathy and its therapeutic intervention. Curr. Drug Targets 2007; 8(8): 952-959.

Yamagishi S. Role of advanced glycation end products (AGEs) and receptor for AGEs (RAGE) in vascular damage in diabetes. Exp. Gerontol 2011; 46(4): 217-224.

Yokoyama M, Tanigawa K, Murata T. Dietary polyunsaturated fatty acids slow the progression of diabetic nephropathy in streptozotocin-induced diabetic rats. Nutr. Res 2010; 30(3): 217-225.

Yokozawa T, Nakagawa T, Wakaki K, Koizumi F. Animal model of diabetic nephropathy. Exp. Toxicol. Pathol 2001; 53(5): 359-363.

Zhang W, Patil S, Chauhan B. FoxO1 regulates multiple metabolic pathways in the liver effects on gluconeogenic, glycolytic, and lipogenic gene expression. J. Biol. Chem 2006; 281(15): 10105-10117

Ziyadeh FN, Hoffman BB, Han DC. Long-term prevention of renal insufficiency, excess matrix gene expression, and glomerular mesangial matrix expansion by treatment with monoclonal antitransforming growth factor-beta antibody in db/db diabetic mice. Proc. Natl. Acad. Sci. U. S. A 2000; 97(14): 8015-8020. doi:10.1073/pnas.120055097. 